\title{
Doerr's theory of morphogenesis of arterial transposition in light of recent research
}

\author{
BENEDICTO CHUAQUI \\ From the Department of Pathology, Catholic University, Santiago, Chile
}

SUMMARY Doerr's theory of the morphogenesis of transposition is discussed with special reference to recent studies by Goor and co-workers and Anderson and associates. The views advanced by all these authors coincide in three points: (a) the description of the reorganisation process occurring at the arterial end of the embryonic heart (a process called by Doerr vectorial bulbus rotation); (b) the pathogenetic interpretation of transposition as the result of an arrest of vectorial bulbus rotation; (c) the recognition of a teratological series or spectrum of anomalies pathogenetically related to transposition. Vectorial bulbus rotation is explained mainly as the result of three largely simultaneous events: bulbar shift, bulbus torsion, and truncus torsion. The spectrum of anomalies related to transposition appears as a close-knit series. Bulbar retraction does not seem to be a necessary condition for the connection of the aorta to the left ventricle.

During the 1970's, Goor and associates in the United States (Goor et al., 1972; Goor and Edwards, 1973; Goor and Lillehei, 1975) and Anderson et al. (1974a, b) in Britain have developed similar theories concerning the morphogenesis of transposition, which coincide in their main features with that formulated by Doerr 26 years ago (Doerr, 1952). This concordance of 3 independent sources is the more significant, since Doerr's contributions to the subject (Doerr, 1952, 1955a, b, 1960, 1970) seem to have been unknown to the later authors. There is also a remarkable similarity in the arguments used by Doerr (1938, 1943) and by Anderson's group (Anderson et al., 1974a; Macartney et al., 1976) to refute the pathogenetic concept of the straight bulbotruncal septum (Rokitansky, 1875) which in recent years has been postulated by de la Cruz and Pio da Rocha (1956) and de la Cruz et al. (1959, 1967, 1971).

Agreement exists on 3 essential points:

(1) The morphological features of the reorganisation occurring at the arterial end of the embryonic heart, a complex process denoted by Doerr vectorial bulbus rotation (see Fig.); (2) an arrest of this process as the main pathogenetic mechanism causing transposition; and (3) the existence of a teratological series, or spectrum, of anomalies pathogenetically related to transposition.

Received for publication 21 March 1978
However, Anderson and associates depart from Doerr and from Goor and co-workers in assigning a similar significance to bulbar shrinkage as bulbar atrophy has in Keith's theory (1909), to which Van Praagh's conal growth hypothesis (Van Praagh and Van Praagh, 1966, 1967; Van Praagh et al., 1967, 1971 ) is also related (cf. Anderson et al., 1974a; Chuaqui and Bersch, 1973). But Van Praagh's concept of conal inversion (Van Praagh and Van Praagh, 1966) - (unfortunately, Goor and associates use the same expression with a very different meaning, namely that of the normal bulbotruncal torsion)shows some relation to Pernkopf and Wirtinger's belief in the inverse development of the septum bulbi as the cause of transposition (Pernkopf and Wirtinger, 1933, 1935; Wirtinger, 1937). In fact, according to Van Praagh's definition of the conus (Van Praagh and Van Praagh, 1966), the position of the great arteries depends also on how the bulbar septum develops. This is why the objections of Goor and Edwards (1973) to the conal growth hypothesis are also valid with respect to the concept of (using Doerr's expression) the septatio aberrans transponans bulbi. With almost the same words as those used by Doerr (1955a), they conclude that transposition is determined before the bulbar septum develops, and that the presence or absence of a conus is incidental rather than causal. As for the contribution of Pernkopf and Wirtinger it is especially important to distinguish between its 


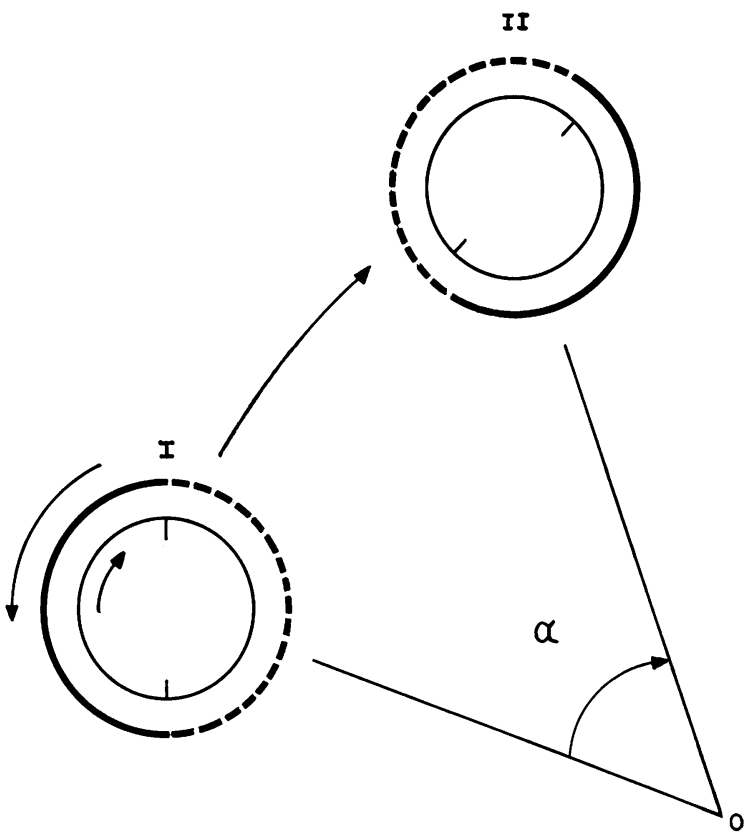

Fig. Diagram of the vectorial bulbus rotation (caudal view; ventral: top of the figure). I: initial state, II: end state. Outer circles: bulbotruncal orifice (solid line: aortic bed; broken line: pulmonary bed); inner circles: bulbometampullar orifice. a: bulbus displacement. $O: a$ point of reference dorsal to the bulbotruncal segment. The combination of rotation of the bulbus around its long axis and rotation around the fixed point $O$ resembles movement of a planet round the sun; hence the term vectorial bulbus rotation.

descriptive and its interpretative aspects, the former having been widely confirmed by several authors, including Doerr, but the latter representing the antithesis to Doerr's views (for a detailed discussion of this topic, see Goerttler, 1963).

Thus, viewed historically, theories on transposition have evolved in a cyclical manner, classical pathogenetic ideas re-emerging to be argued on a more secure basis, though Spitzer's phylogenetic theory (1923), reformulated by Lev and Saphir (1945), in combination with Pernkopf and Wirtinger's ontogenetic theory, seems to have remained separate from this evolution.

What follows in this brief paper is subdivided into 3 parts: comments on (a) vectorial bulbus rotation as verified in recent studies; (b) the concept of a teratological series with special reference to the spectrum of transposition; (c) the significance of bulbar shrinkage.

\section{(a) Vectorial bulbus rotation}

This complex process may be conceived as the result of 3 components which occur more or less simultaneously (Fig.).

(i) Leftward shift of the bulbus in toto with concomitant enlargement of the metampulla (horizons XIII-XVIII, de Vries and Saunders, 1962; Asami, 1969) and with shrinkage of the bulbus and elongation of the truncus (horizons XVI-XVIII, Asami, 1969; Chuaqui and Bersch, 1972, 1973; horizons XVI-XIX according to Goor et al., 1972).

(ii) Torsion of the bulbus at the bulbometampullar orifice through $45^{\circ}$ clockwise rotation (looking downstream) (horizons XV-XVI, Asami, 1969).

(iii) Torsion of the truncus at the bulbotruncal orifice through $150^{\circ}$ counterclockwise rotation (looking downstream) (horizons XV-XX, Asami, 1969; Chuaqui and Bersch, 1972, 1973; through 90-110 ${ }^{\circ}$ according to Goor et al., 1972).

The sequence of these events is illustrated in Table 1. For the timing of ventricular septation (development of ventricular septum, truncus and bulbus septation, and closure of the interventricular foramen) see de Vries and Saunders (1962), Asami (1969), Goor et al. (1970), and Chuaqui and Bersch (1972, 1973). However, some discrepancies exist about the data presented in Table 1 . Thus, for example, the ventricular septum is already present in horizon XIII according to Goor et al. (1970). Completion of the truncal septum is variously

Table 1 Components of vectorial bulbus rotation and ventricular septation

\begin{tabular}{|c|c|c|c|c|c|c|c|c|}
\hline $\begin{array}{l}\text { Horizon } \\
\text { Ovulation age (days) }\end{array}$ & $\begin{array}{l}X I I I \\
28\end{array}$ & $\begin{array}{l}X I V \\
29\end{array}$ & $\begin{array}{c}X V \\
31\end{array}$ & $\begin{array}{l}X V I \\
33\end{array}$ & $\underset{35}{X V I I}$ & $\underset{37}{X V I I I}$ & $\underset{39}{X I X}$ & $\underset{41}{X X}$ \\
\hline
\end{tabular}

Bulbus shifting

Bulbus torsion

Truncus torsion

Bulbar shrinkage

Ventricular septum

Truncus septum

Fusion of bulbar ridges

Closure of interventricular foramen

$\star$ After Streeter (1945, 1948, 1951). 
Table 2 Teratogenetic periods of main prototypes in transposition series

\begin{tabular}{|c|c|c|c|c|c|c|c|c|}
\hline $\begin{array}{l}\text { Horizon }{ }^{\star} \\
\text { Ovulation age (days) }\end{array}$ & $\begin{array}{l}X I I I \\
28\end{array}$ & $\begin{array}{l}X I V \\
29\end{array}$ & $\begin{array}{l}X V \\
31\end{array}$ & $\begin{array}{l}X V I \\
33\end{array}$ & $\begin{array}{l}X V I I \\
35\end{array}$ & $\begin{array}{l}X V I I I \\
37\end{array}$ & $\begin{array}{l}X I X \\
39\end{array}$ & $\underset{41}{X X}$ \\
\hline $\begin{array}{l}\text { Cor bulboventriculare } \\
\text { Beuren transposition } \\
\text { Complete transposition } \\
\text { Taussig-Bing anomaly } \\
\text { Tetralogy of Fallot } \\
\text { Eisenmenger complex }\end{array}$ & - & - & 一 & - & & & & \\
\hline
\end{tabular}

*After Streeter $(1945,1948,1951)$.

thought to occur at the following points: horizon XVI (Goor et al., 1972; Anderson et al., 1974b), horizon XVIII (Neill, 1956), horizon XIX (O'Rahilly, 1971); bulbar septation is completed in horizon XVII according to Anderson et al. (1974b).

Before bulbotruncal torsion the bulbar ridges run in a conspicuously twisted spiral, whereas at the truncus a straight septum develops. Torsion of the bulbotruncal orifice produces different effects on these septa: at the truncus it causes the primarily straight-structured septum to become helical, and at the bulbus it considerably reduces the extent to which the ridges spiral; torsion of the bulbometampullar orifice and bulbar shrinkage also contribute to this last effect (Fig.) (cf. Los, 1966, 1968; Chuaqui and Bersch, 1972, 1973; Goor et al., 1972; Anderson et al., 1974b).

\section{(b) Concept of teratological series}

This concept was introduced by Schwalbe (1906) and applied to cardiac teratology probably for the first time by Spitzer (1923). In the following brief account, previous ideas (Chuaqui, 1971) are elaborated, taking into account Bersch and Doerr's recent contribution (1976).

It is to Doerr's credit that he recognised in the apparently heterogeneous group of malformations known as Eisenmenger's complex, Fallot's tetralogy, the Taussig-Bing anomaly, and complete transposition, the existence of a teratological series (Doerr, 1951), and inferred from it the morphogenetic relation between these anomalies (Doerr, 1952).

A teratological series is a set of developmental anomalies that may be thought of as varieties of a similar basic morphological pattern. The members of such a series are thus related to one another in their visible form. However, the great heuristic value of this concept lies in the fact that these various entities may each represent distinct manifestations of a similar disturbance occurring at different times in development, in which case the members of the series are also morphogenetically linked. The series is then limited, on the one extreme, by the earliest, usually the most severe malformation, and on the other, by the last-occurring anomaly, representing the least deviation from normal. In the case of transposition, the morphogenetic accident involved is an arrest to a varying extent of vectorial bulbus rotation. The teratogenetic periods of some exemplars of this series are presented in Table 2 (cf Chuaqui and Bersch, 1972, 1973). Viewed the other way, analysis of the transposition series can serve to clarify the nature of a hypothetical, and complex, process of development, if this means that each member of the series has to be explained by a disturbance of that process. Such analysis then shows that the original series can be extended by additional entities which appear as transitional forms between the classical members (Chuaqui, 1969), for example, the cor bulboventriculare of Goor and Edwards (1972), equivalent to Goerttler's primitive laevocardia (1958, 1963, 1968), and Beuren's transposition (1960) (cf Chuaqui, 1969). This has happened more and more in recent years and the teratological series of transposition could now be described as a close-knit one in the sense that it is possible to conceive of a transitional anomaly between any two existing members. Thus, by the very recognition of the quasicontinuous nature of the series, one may infer that the underlying mechanism producing it ought to have the character of a biological continuum, as indeed a process of bulbus rotation has. This explains why it is impossible to categorise all its manifestations into a progression of well-defined, fixed entities; in systematisation one can only consider the intervals where well-recognised prototypes recur. Conventional distinctions seem of no decisive importance. In the Anglo-American papers concerning transposition and related lesions the expression spectrum or continuous spectrum of anomalies is used with a similar meaning to that of teratological series (Gessner, 1966; Gessner and Van Mierop, 1970; Lev et al., 1972; Goor and Edwards, 1973; Anderson et al., 1974a; Patterson et al., 1974; Becker et al., 1975; Rosenquist et al., 1976).

From this approach it should not be concluded that the anomalous forms of the transposition series 
represent normal stages of cardiac development; processes of adaptation occur and there are likely to be other and different disturbances of vectorial bulbus rotation (cf Goerttler, 1963; Chuaqui and Bersch, 1973; Anderson et al., 1974a), thus multiplying the possibilities.

\section{(c) Comments on significance of bulbar retraction}

Bulbar shrinkage is a proven fact which is particularly evident in horizon XVII (Asami, 1969; Goor et al., 1972; Anderson et al., 1974b). According to Goor et al. (1972) it begins after bulbar migration when half of the truncal torsion is completed. Nevertheless, as Chuaqui and Bersch (1973) point out, it is difficult to establish whether bulbar retraction merely accompanies vectorial bulbus rotation or is partly a cause of it. Anderson et al. $(1974 a, b)$ adopted the second alternative in considering it to be the cause of bulbar migration, and thus assigned to it a decisive role in the connection of the aorta to the future left ventricle. A failure of bulbar retraction would then imply, besides persistence of the bulbuauricular flange and a lack of mitral-aortic fibrous continuity, at least an overriding aorta. Until the case described by Bersch et al. (1975) it was impossible to know whether this introduction of an additional factor was correct or not, but here, as so often, teratology came to the rescue. These workers reported for the first time a malformation characterised by normally positioned great vessels, adult type morphology of the ventricles, except for a long muscular aortic conus measuring $4 \mathrm{~cm}$, and absence of mitral-aortic fibrous continuity. Bulbar retraction, therefore, may be vital for the atrophy of the left portion of the bulboauricular flange and for the establishment of mitral-aortic fibrous continuity (cf Chuaqui and Bersch, 1973; Anderson et al., 1974a, b), but this case shows that it is not a necessary condition for the connection of the aorta to the left ventricle.

\section{References}

Anderson, R. H., Wilkinson, J. L., Arnold, R., Becker, A. E., and Lubkiewicz, K. (1974a). Morphogenesis of bulboventricular malformations. II. Observations on malformed hearts. British Heart fournal, 36, 948-970.

Anderson, R. H., Wilkinson, J. L., Arnold, R., and Lubkiewicz, K. (1974b). Morphogenesis of bulboventricular malformations. I. Consideration of embryogenesis in the normal heart. British Heart fournal, 36, 242-255.

Asami, I. (1969). Beitrag zur Entwicklung des Kammerseptums im menschlichen Herzen mit besonderer Berücksichtigung der sogenannten Bulbusdrehung. Zeitschrift für Anatomie und Entwicklungsgeschichte, 128, 1-17.

Becker, A. E., Connor, M., and Anderson, R. H. (1975). Tetralogy of Fallot: a morphometric and geometric study.
American fournal of Cardiology, 35, 402-412.

Bersch, W., Chuaqui, B., and Heilmann, K. (1975). Persistenz des primitiven Aortenconus bei regelrechter Stellung der grossen Gefässe des Herzens. Virchows Archiv A. Pathological Anatomy and Histology, 368, 299-307.

Bersch, W., and Doerr, W. (1976). Reitende Gefässe des Herzens. Homologiebegriff und Reihenbildungen. SpringerVerlag, Berlin, Heidelberg, and New York.

Beuren, A. J. (1960). Differential diagnosis of the TaussigBing heart from a complete transposition of the great vessels with a posteriorly overriding pulmonary artery. Circulation, 21, 1071-1087.

Chuaqui, B. (1969). Zur Terminologie einiger Herzheterotopien. Virchows Archiv Abteilung A, Pathology Pathologische Anatomie, 347, 260-276.

Chuaqui, B. (1971). Ueber die Dextropositio aortae (Bemerkungen zur Auffassung von H. Bankl). Beiträge zur Pathologie, 144, 394-399.

Chuaqui, B., and Bersch, W. (1972). The periods of determination of cardiac malformations. Virchows Archiv Abteilung A, Pathology Pathologische Anatomie, 356, 95-110.

Chuaqui, B., and Bersch, W. (1973). The formal genesis of the transposition of the great arteries. Virchows Archiv Abteilung A, Pathology Pathologische Anatomie, 358, 11-34.

de la Cruz, M. V., Anselmi, G., Cisneros, F., Reinhold, M., Portillo, B., and Espino-Vela, J. (1959). An embryologic explanation for the corrected transposition of the great vessels: additional description of the main anatomic features of this malformation and its varieties. American Heart Fournal, 57, 104-117.

de la Cruz, M. V., Anselmi, G., Muños-Castellanos, L. Nadal-Ginard, B., and Muñoz-Armas, S. (1971). Systematization and embryological and anatomical study of mirror image dextrocardias, dextroversions, and laevoversions. British Heart fournal, 33, 841-853.

de la Cruz, M. V., Espino-Vela, J., Attie, F., and Muñoz, C. L. (1967). An embryological theory for the ventricular inversions and their classification. American Heart fournal, 73, 777-793.

de la Cruz, M. V., and Pio da Rocha, J. (1956). An ontogenetic theory for the explanation of congenital malformations involving the truncus and conus. American Heart fournal, 51, 782-805.

de Vries, P. A., and Saunders, J. C. M. (1962). Development of the ventricles and spiral outflow tract in the human heart. Contributions to Embryology, 37, 87-114.

Doerr, W. (1938). Zur Transposition der Herzschlagadern. Ein kritischer Beitrag zur Lehre der Transpositionen. Virchows Archiv für pathologische Anatomie und Physiologie, 303, 168-205.

Doerr, W. (1943). Ueber Missbildungen des menschlichen Herzens mit besonderer Berücksichtigung von Bulbus und Truncus. Virchows Archiv für pathologische Anatomie und Physiologie, 310, 304-368.

Doerr, W. (1951). Pathologische Anatomie typischer Grundformen angeborener Herzfehler. Monatsschrift für Kinder-

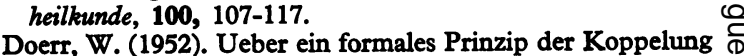
von Entwicklungsstörungen der venösen und arteriellen $\stackrel{?}{+}$ Kammerostien. Zeitschrift für Kreislaufforschung, 41, 269-284.

Doerr, W. (1955a). Die formale Entstehung der wichtigsten $\frac{\mathrm{C}}{\mathbb{D}}$ Missbildungen des arteriellen Herzendes. Beiträge zur pathologischen Anatomie und zur allgemeinen Pathologie, 115, 1-32.

Doerr, W. (1955b). Missbildungen des Herzens und der $\widetilde{\sigma}$ grossen Gefässe. In Lehrbuch der speziellen pathologischen $?$ Anatomie, vol. $\mathrm{I} / 1$, p. 381 , ed E. Kaufmann and $\mathrm{M}$. Staemmler. W. de Gruyter, Berlin. 
Doerr, W. (1960). Pathologische Anatomie der angeborenen Herzfehler. In Handbuch der inneren Medizin, 4th edn, Vol. 9, Part 3, pp. 1-104, ed G. von Bergmann, W. Frey, and H. Schwiegk. Springer, Berlin, Göttingen, and Heidelberg.

Doerr, W. (1970). Allgemeine Pathologie der Organe des Kreislaufes. In Handbuch der allgemeinen Pathologie, Vol. 3, Part 4, pp. 205-752, ed H. Meessen and F. Roulet. Springer, Berlin, Heidelberg, and New York.

Gessner, I. H. (1966). Spectrum of congenital cardiac anomalies produced in chick embryos by mechanical interference with cardiogenesis. Circulation Research, 18, 625-633.

Gessner, I. H., and Van Mierop, L. H. S. (1970). Experimental production of cardiac defects: the spectrum of dextroposition of the aorta. American fournal of Cardiology, 25, 272-278.

Goerttler, K. (1958). Normale und pathologische Entwicklung des menschlichen Herzens. Vol. 4. Thieme, Stuttgart.

Goerttler, K. (1963). Die Missbildungen des Herzens und der grossen Gefässe. In Das Herz des Menschen, Vol. I, p. 422, ed W. Bargmann and W. Doerr. Thieme, Stuttgart.

Goerttler, K. (1968). Die Missbildungen des Herzens und der grossen Gefässe. In Lehrbuch der speziellen pathologischen Anatomie, 11th and 12th edn, Suppl. to Vol. I/1, p. 1. W. de Gruyter, Berlin.

Goor, D. A., Dische, R., and Lillehei, C. W. (1972). The conotruncus. I. Its normal inversion and conus absorption. Circulation, 46, 375-384.

Goor, D. A., and Edwards, J. E. (1972). The conotruncus. II. Report of a case showing persistent aortic conus and lack of inversion of the truncus (a bulboventricular heart). Circulation, 46, 385-389.

Goor, D. A., and Edwards, J. E. (1973). The spectrum of transposition of the great arteries, with special reference to developmental anatomy of the conus. Circulation, 48, 406-415.

Goor, D. A., Edwards, J. E., and Lillehei, C. W. (1970). The development of the interventricular septum of the human heart; correlative morphogenetic study. Chest, 58, 453-467.

Goor, D. A., and Lillehei, W. C. (1975). Congenital Malformations of the Heart. Embryology, Anatomy, and Operative Considerations. Grune and Stratton, New York, San Francisco, and London.

Keith, A. (1909). The Hunterian lectures on malformations of the heart. Lecture II. Lancet, 2, 433-435.

Lev, M., Bharati, S., Meng, C. C. L., Liberthson, R. R., Paul, M. H., and Idriss, F. (1972). A concept of doubleoutlet right ventricle. Fournal of Thoracic and Cardiovascular Surgery, 64, 271-281.

Lev, M., and Saphir, O. (1945). A theory of transposition of the arterial trunks based on the phylogenetic and ontogenetic development of the heart. Archives of Pathology, 39, 172-183.

Los, J. A. (1966). Le cloisennement du tronc artériel chez l'embryon humain. Comptes Rendus de l'Association des Anatomistes, 50, 682-686.

Los, J. A. (1968). Embryology. In Paediatric Cardiology, pp. $1-28$, ed H. Watson. Lloyd-Luke, London.

Macartney, F. J., Shinebourne, E. A., and Anderson, R. H. (1976). Connexions, relations, discordance, and distorsions. British Heart fournal, 38, 323-326.

Neill, C. A. (1956). Development of the pulmonary veins. With reference to the embryology of anomalies of the pulmonary venous return. Pediatrics, 18, 880-887.

O'Rahilly, R. (1971). The timing and sequence of events in human cardiogenesis. Acta Anatomica, 79, 70-75.

Patterson, D. F., Pyle, R. L., Van Mierop, L., Melbin, J., and Olson, M. (1974). Hereditary defects of the conotruncal septum in Keeshond dogs: pathologic and genetic studies. American fournal of Cardiology, 34, 187-205.

Pernkopf, E., and Wirtinger, W. (1933). Die Transposition der Herzostien. Ein Versuch der Erklärung dieser Erscheinung. Die Phoronomie der Herzentwicklung als morphologische Grundlage der Erklärung. Zeitschrift für Anatomie und Entwicklungsgeschichte, 100, 563-711.

Pernkopf, E., and Wirtinger, W. (1935). Das Wesen der Transposition im Gebiet des Herzens, ein Versuch der Erklärung auf entwicklungsgeschichtlicher Grundlage. Virchows Archiv für pathologische Anatomie, 295, 143-174.

Rokitansky, C. V. (1875). Die Defekte der Scheidewände des Herzens. Braunmüller, Vienna.

Rosenquist, G. C., Clark, E. B., Sweeney, L. J., and McAllister, H. A. (1976). The normal spectrum of mitral and aortic valve discontinuity. Circulation, 54, 298-301.

Schwalbe, E. (1906). Die Morphologie der Missbildungen des Menschen und der Tiere. Part I: Allgemeine Missbildungslehre (Teratologie). G. Fischer-Verlag, Jena.

Spitzer, A. (1923). Ueber den Bauplan des missgebildeten Herzens. Virchows Archiv für pathologische Anatomie, 243, 81-272.

Streeter, G. L. (1945). Developmental horizons in human embryos: description of age group XIII, embryos about 4 or 5 millimetres long, and age group XIV, period of indentation of lens vesicle. Contributions to Embryology, 31, 27-64.

Streeter, G. L. (1948). Developmental horizons in human embryos: description of age groups XV, XVI, XVII, and XVIII. Contributions to Embryology, 32, 133-204.

Streeter, G. L. (1951). Developmental horizons in human embryos: description of age groups XIX, XX, XXl, XXII, and XXIII. Contributions to Embryology, 34, 165-196.

Van Praagh, R., Perez-Trevino, C., Lopez-Cuellar, M., Baker, F. W., Zuberbuhler, J. R., Quero, M., Perez, V. M., Moreno, F., and Van Praagh, S. (1971). Transposition of the great arteries with posterior aorta, anterior pulmonary artery, subpulmonary conus and fibrous continuity between aortic and atrioventricular valves. American fournal of Cardiology, 28, 621-631.

Van Praagh, R., and Van Praagh, S. (1966). Isolated ventricular inversion. A consideration of the morphogenesis, definition and diagnosis of nontransposed and transposed great arteries. American fournal of Cardiology, 17, 395-406.

Van Praagh, R., and Van Praagh, S. (1967). Anatomically corrected transposition of the great arteries. British Heart fournal, 29, 112-119.

Van Praagh, R., Vlad, P., and Keith, J. D. (1967). Complete transposition of the great arteries. In Heart Disease in Infancy and Childhood, 2nd edn, pp. 682-744, ed J. D. Keith, R. Rowe, and P. Vlad. Macmillan, New York.

Wirtinger, W. (1937). Die Analyse der Wachstumsbewegungen under der Septierung des Herzschlauches. Anatomischer Anzeiger, 84, 33-79.

Requests for reprints to Professor J. B. Chuaqui, Department of Pathology, Catholic University, Marcoleta 357, Santiago, Chile. 